\title{
The Effects of Night-time Temperatures on Physiological and Biochemical Traits in Rice
}

\section{Oscar H. ALVARADO-SANABRIA ${ }^{1}$, Gabriel A. GARCES-VARON², Hermann RESTREPO-DIAZ ${ }^{3 *}$}

\author{
${ }^{1}$ Universidad Pedagógica y Tecnológica de Colombia, Faculty of Agricultural Sciences, Agricultural Research Group, Tunja, \\ Colombia; ohalvarados@unal.edu.co \\ ${ }^{2}$ Federación Nacional de Arroceros, Seccional Saldaña, Carrera 18 No 23-112, 733570 Saldaña, Colombia; gabrielgarces@fedearroz.com.co \\ ${ }^{3}$ Universidad Nacional de Colombia, Facultad de Ciencias Agrarias, Departamento de Agronomia, Carrera 30 No 45-03, 111321 Bogotá, \\ Colombia; hrestrepod@unal.edu.co (*corresponding author)
}

\begin{abstract}
High nighttime temperatures impair rice yield. Additionally, heat stress periods have increased during the last years in the rice areas of the tropics. The aim of this study was to physiologically characterize six genotypes of rice (a commercial cultivar ('F60') and five selected lines ('IR 1561', 'FLO 2764', 'LV447-1', 'CT19021', and 'LV1401') subjected to two nighttime temperatures $\left(24\right.$ and $30^{\circ} \mathrm{C}$ ), based on different physiological traits. When the collar formed on leaf 6 of the main stem, one group of six plants in each genotype was subjected to $30^{\circ} \mathrm{C}$ from 18:00 to 24:00 hours for eight days, while the other group remained at $24^{\circ} \mathrm{C}$. Differences were found in the interaction between genotype and nighttime temperatures, where a high night temperature reduced leaf photosynthesis by approximately $50 \%$ in all genotypes compared to the controls $(20 \mu \mathrm{mol} v \mathrm{vs}$ $10 \mu \mathrm{mol} \mathrm{CO} \mathrm{C}^{-2} \mathrm{~s}^{-1}$, respectively). In general, higher plant respiration was also observed in almost all genotypes when the plants were exposed to $30^{\circ} \mathrm{C}$. However, rice plants of the genotype 'F60' showed a constant respiration under two different night temperatures. A high nighttime temperature increased the electrolyte leakage and malondialdehyde content only in the 'LV1401' plants. Plant growth and $\mathrm{F}_{\mathrm{v}} / \mathrm{F}_{\mathrm{m}}$ ratio were separately conditioned by the night temperature or the genotype factor. A lower total plant dry weight was found at $30^{\circ} \mathrm{C}(620.36 \mathrm{mg})$ than in rice plants exposed to $24^{\circ} \mathrm{C}(254.16 \mathrm{mg})$. The $\mathrm{F}_{\mathrm{v}} / \mathrm{F}_{\mathrm{m}}$ ratio was slightly diminished at a high nighttime temperature. These results suggest that physiological variables, such as leaf photosynthesis, plant respiration, malondialdehyde content and leaf photosynthetic pigments, can be considered markers for characterizing tolerant genotypes in earlier growth phases during plant breeding programs.
\end{abstract}

Keywords: $\mathrm{F}_{\mathrm{v}} / \mathrm{F}_{\mathrm{m}}$ ratio, leaf photosynthetic pigments, Oryza sativa L, oxidative stress, proline

\section{Introduction}

Global warming has generated adverse weather conditions, such as heavy and prolonged periods of drought and more frequent periods of high temperatures, in several regions of the world in recent years (FAO, 2002). In Colombia, climate change has led to an approximately $1{ }^{\circ} \mathrm{C}$ increase in the mean temperature during the last twenty years (Ballesteros and Enciso, 2012). Additionally, periods of high nighttime temperatures have reduced grain yields in the rice-growing areas of Colombia, thus reducing the crop productivity of one of the most economically important cereals during the last decade (FEDEARROZ, 2013).

High night temperatures (HNT) cause plant responses at the biochemical, physiological and/or genetic level. A high night temperature can reduce the leaf photosynthesis rate and increase plant respiration (Mohammed and Tarpley, 2010).
Earlier studies have shown that rice plants exposed to high night temperatures $\left(35^{\circ} \mathrm{C}\right)$ had low $\mathrm{CO}_{2}$ assimilation due to lower PSII efficiency and ribulose 1-5 bisphosphate carboxylase/oxidase activity (Yin et al., 2010). In rice, higher plant respiration was observed in the vegetative stage due to HNT (Kanno et al, 2009).

On the other hand, plant acclimatization is also associated with genotype (Wahid et al., 2007; Jha et al., 2014). Several studies have shown that tolerant genotypes have a series of biochemical and physiological changes to cope with heat stress (Bita and Gerats, 2013; Kumar et al., 2016). Kumar et al. (2012) stated that susceptible rice genotypes could show greater membrane damage, greater malondialdehyde and proline levels, and a loss of chlorophyll. Therefore, the use of different biochemical and physiological traits has been helpful to screen, and then select, genotypes that are tolerant to high night temperatures (Araus et al., 2008). 
158

The physiological, biochemical and molecular plant responses to heat stress are regulated by a cascade of events (Hasanuzzaman et al., 2013). Knowledge of the physiological mechanisms associated with the interaction between genotype $(\mathrm{G})$ and environment $(\mathrm{E})$ has been one of the bottlenecks in breeding programs (Jha et al., 2014). In this regard, rice seedling studies have become an important tool to understand, in depth, the physiological mechanisms involved in plant tolerance to heat stress conditions during the last years (Xue $e t$ al., 2012; Sánchez-Reinoso et al., 2014).

Laza et al. (2015) also stated that most studies during the vegetative phase have provided supporting evidence of how HNT might affect rice physiology and an understanding of the physiological mechanisms that are involved. Consequently, it is important to expand our knowledge of the $\mathrm{Gx}$ E interaction by gaining a better understanding of the physiological and biochemical processes that are involved; this has allowed the use of different techniques to screen genotypes for the development of new, tolerant genotypes in Colombia (FEDEARROZ, 2013). Therefore, our hypothesis was that high night temperatures would increase plant respiration and decrease photosynthesis rates, which would induce oxidative damage by increasing leaf MDA and proline levels as well as causing changes in leaf photosynthetic pigments, resulting in reduced plant growth in susceptible genotypes. Consequently, the objective of this study was to evaluate the use of a series of physiological and biochemical variables to screen the plant tolerance of six rice genotypes in two nighttime temperatures.

\section{Materials and Methods}

\section{Generalgrowingconditions}

An experiment was conducted under greenhouse and laboratory conditions located at the Faculty of Agricultural Sciences of the Universidad Nacional de Colombia, Bogotá. The growing conditions in the greenhouse were as follows: day/night temperature $\left(30 / 24^{\circ} \mathrm{C}\right)$, relative humidity $(70 \%)$ and a natural photoperiod of $12 \mathrm{~h}$. Rice seeds were sown in the superior portion of 450-mL plastic pots containing a loamy soil. After seed germination, seedlings were fertirrigated daily with $80 \mathrm{~mL}$ of a nutrient solution containing a complete fertilizer (Wuxal," Bayer CropScience, Bogotá D.C., Colombia) at a rate of $2 \mathrm{~mL} \mathrm{~L}^{-}$ ${ }^{1} \mathrm{H}_{2} \mathrm{O}$. The fertilizer concentration was as follows: total nitrogen $160 \mathrm{gL}^{-1}$, (ammonia N, $38 \mathrm{~g} \mathrm{~L}^{-1}$; nitric N, $12 \mathrm{gL}^{-1}$; urea N, $110 \mathrm{~g}$ $\left.\mathrm{L}^{-1}\right)$, assimilable $\mathrm{P}\left(\mathrm{P}_{2} \mathrm{O}_{5}\right) 160 \mathrm{gL}^{-1}$; soluble $\mathrm{K}\left(\mathrm{K}_{2} \mathrm{O}\right) 120 \mathrm{~g} \mathrm{~L}^{-1} ; 10$ $\mathrm{gBL}^{-1} ; 0.21 \mathrm{gCu} \mathrm{L}^{-1} ; 0.43 \mathrm{~g} \mathrm{Fe} \mathrm{L}^{-1} ; 0.36 \mathrm{~g} \mathrm{Mn} \mathrm{L}^{-1} ; 0.07 \mathrm{gMo} \mathrm{L}^{-1}$; $10 \mathrm{gZn} \mathrm{L}^{-1^{*}}\left({ }^{*}\right.$ Chelated with EDTA - pH of $10 \%$ 6.5; density at $\left.25^{\circ} \mathrm{C} 1.40 \mathrm{~g} \mathrm{~cm}^{-3}\right)$.

\section{Treatments}

A susceptible genotype (' $\mathrm{F} 60$ ') to high daytime temperatures (Sánchez-Reinoso et al, 2014) and five genotypes used by the National Rice Growers Association in their breeding programs ('IR 1561', 'FLO 2764', 'LV447-1', 'CT19021', and 'LV1401') were evaluated. At 32 days after seed germination (DAG), when the rice plants showed collar formation on leaf 6 on the main stem (V6 stage), rice seedlings were split into two groups of six plants per genotype. The first group was always placed under greenhouse conditions (control plants). In the second group of plants, rice plants were moved into a growth chamber (MLR-351H, Sanyo, Bensenville, Illinois, USA) at
$30{ }^{\circ} \mathrm{C}$ between 1800 and $2400 \mathrm{~h}$ (HNT plants). Then, plants were returned to the greenhouse conditions between 0000 and $1800 \mathrm{~h}$ for 8 days. In general, rice plants were exposed to nighttime temperature treatments for eight days because of the physiological and biochemical alterations that were observed in a previous experiment (Alvarado-Sanabria et al., 2017). Finally, we used a night temperature of $24^{\circ} \mathrm{C}$ as the control temperature because it is the average night temperature in many rice areas, while $30^{\circ} \mathrm{C}$ is the most common night temperature registered during heat stress periods in Colombia.

\section{Photosynthesis}

A mature leaf from the main stem of each plant was used to determine leaf photosynthesis using a portable photosynthesis meter (LI-COR 6200, Lincoln, Nebraska, USA) between 37 and 40 DAG. During the photosynthesis measurements, the conditions in the instrument chamber were: Photosynthetic Active Radiation (PAR) greater than $800 \mu \mathrm{mol} \mathrm{m} \mathrm{m}^{-2} \mathrm{~s}^{-1}$, leaf temperature $27 \pm 5^{\circ} \mathrm{C}$, vapor pressure deficit $1.8 \pm 0.5 \mathrm{kPa}$. The readings were carried out between 0900 and 1200 h. Finally, six plants per treatment (temperature $\mathrm{x}$ genotype) were taken collected to determine the $\mathrm{CO}_{2}$ assimilation rate by putting a rice leaf into the chamber of the instrument.

\section{Plant respiration}

The methodology described by Sánchez-Reinoso et al. (2014) was followed to estimate the total plant respiration in total darkness, either in greenhouse or chamber conditions. This method consisted of introducing plants in 2-L airtight plastic chambers. Subsequently, $\mathrm{CO}_{2}$ infrared sensors (CO2-BTA, Vernier, Beaverton, OR, USA) were inserted into the chambers and connected to a portable interface (LabQuest, Vernier, Beaverton, OR, USA). Before placing the plants in the sealed chambers, all pots were covered with a plastic wrap to prevent soil respiration, which allowed us to quantify the plant tissue respiration only. Then, the sensor estimated a $\mathrm{CO}_{2}\left(\mathrm{mg} \mathrm{L}^{-1}\right)$ concentration in the chamber every 4 seconds (s) for $300 \mathrm{~s}$, resulting in a linear trend line. Then, the linear regression slope $\left(\mathrm{ppm} \mathrm{s} \mathrm{s}^{-1}\right)$ was determined to obtain the total plant respiration rate using the total plant fresh weight $\left(\mathrm{mmol} \mathrm{CO}_{2} \mathrm{~kg} \mathrm{FW}^{-1} \mathrm{~h}^{-1}\right)$. The plant respiration readings were performed between 2100 and $2400 \mathrm{~h}$ on the same dates and in the same plants that were used in the photosynthesis measurements.

\section{Chlorophyllfluorescence parameters}

$\mathrm{F}_{\mathrm{v}} / \mathrm{F}_{\mathrm{m}}$ ratio measurements were estimated using an MINIPAM modulated fluorometer (Heinz Walz, Effieltrich, Germany). $F_{v} / F_{m}$ readings were recorded by adapting leaves to the dark using lightweight leaf clips for at least 20 min before obtaining the measurements. Chlorophyll fluorescence readings were determined with a maximum light intensity of up to 3000 $\mu \mathrm{mol} \mathrm{m} \mathrm{s}^{-1}$ at the same date and time and in the same leaves that were used to estimate photosynthesis.

\section{Growth parameters}

Leaf area was determined using a leaf area meter LI-3000C (LI-COR Lincoln, Nebraska, USA) at 40 DAG. Then, plants were harvested and dried at $70^{\circ} \mathrm{C}$ for $48 \mathrm{~h}$ to determine the leaf and stem dry weights. Specific leaf mass (leaf dry weight/leaf area) and leaf/stem ratio (leaf mass/stem mass + leaf sheath per plant) were determined. 


\section{Electrolyte leakage (\%)}

At $40 \mathrm{DAG}, 0.3 \mathrm{~g}$ of fresh leaves was cut into $1-\mathrm{cm}$ long pieces and placed in test tubes with $30 \mathrm{~mL}$ of deionized water. Subsequently, the tubes were incubated in a water bath at $30^{\circ} \mathrm{C}$ for two $\mathrm{h}$, and the first electrical conductivity $\left(E C_{I}\right)$ was estimated. The samples were incubated again at $95^{\circ} \mathrm{C}$ in a water bath for $15 \mathrm{~min}$ to release all the electrolytes. The sample was allowed to cool, and the final electrical conductivity $\left(E C_{2}\right)$ was recorded. The electrolyte percentage was calculated using the formula described by Sanchez-Reinoso et al. (2014):

$$
\% \text { Electrolytes }=\left(\frac{E C_{1}}{E C_{2}}\right) \times 100
$$

Chlorophyll and carotenoid content

At 40 DAG, three 1-cm long pieces of veinless leaf blades $(50$ $\mathrm{mg}$ fresh weight) from a fully developed leaf were ground using liquid nitrogen and stored at $-80^{\circ} \mathrm{C}$ until the respective analyses were made. Fifty $\mathrm{mg}$ of fresh leaves was macerated in a mortar with $5 \mathrm{~mL}$ of $80 \%$ acetone, and then the sample was centrifuged at $8000 \mathrm{rpm}$ for $5 \mathrm{~min}$. Then, the absorbance readings at wavelengths of $663 \mathrm{~nm}, 647 \mathrm{~nm}$ and $470 \mathrm{~nm}$ were recorded, and the chlorophyll a, b and carotenoids content $\left(\mathrm{mg} \mathrm{g}^{-1} \mathrm{FW}\right)$ was determined based on Lichtenthaler (1987).

\section{Proline and Malondialdebyde (MDA)}

At $40 \mathrm{DAG}, 300 \mathrm{mg}$ of fully developed leaves from the main stem was ground with liquid nitrogen and stored at $-80^{\circ} \mathrm{C}$ until analysis. Proline content was determined following the Bates et al. (1973) method, where $100 \mathrm{mg}$ of plant tissue was taken and homogenized in $5 \mathrm{~mL}$ of $3 \%$ sulfosalicylic acid. Subsequently, the sample was centrifuged at $6000 \mathrm{rpm}$ for $30 \mathrm{~min}$. Then, $1 \mathrm{~mL}$ of the supernatant was mixed in a falcon tube with $1 \mathrm{~mL}$ of ninhydrin acid and $1 \mathrm{~mL}$ of glacial acetic acid. The above mixture was stirred for $1 \mathrm{~min}$, and then it was subjected to a water bath at $98^{\circ} \mathrm{C}$ for one $\mathrm{h}$. Then, the reaction was stopped with ice. Finally, the reaction mixture was extracted with $3 \mathrm{~mL}$ of toluene, and the tubes were vigorously agitated with a vortex mixer. The absorbance was measured at $520 \mathrm{~nm}$ using a spectrophotometer (Spectronic BioMate 3 UV - Vis, Thermo, Madison, WI, USA). The proline content was determined using a calibration curve and the following formula:

$$
\frac{\mu \text { mol Proline }}{\text { fresh plant material }}=\frac{\left[\frac{\left(\frac{\mu g \text { Proline }}{m L} \times m L \text { Toluene }\right)}{\frac{115.5 \mu g}{\mu m o l}}\right]}{\left[\frac{g \text { sample }}{5}\right]}
$$

MDA content was determined following the Hodges et al. (1999) modified protocol, which was as follows: i) $100 \mathrm{mg}$ of plant material was homogenized in $2 \mathrm{~mL}$ of $0.1 \%$ trichloroacetic acid, ii) the sample was centrifuged at $8000 \mathrm{rpm}$ for $15 \mathrm{~min}$, iii) 1 $\mathrm{mL}$ of supernatant was extracted and mixed with $2 \mathrm{~mL}$ of $20 \%$ trichloroacetic acid and $2 \mathrm{~mL}$ of thiobarbituric acid (+TBA) and, in another test tube, $1 \mathrm{~mL}$ of supernatant was mixed with 2 $\mathrm{mL}$ of $20 \%$ trichloroacetic acid (-TBA), iv) both tubes were stirred for one min and subjected to a water bath at $95^{\circ} \mathrm{C}$ for 30 min, v) the reaction was stopped on an ice bed, and the absorbance values were read at 440,532 and $600 \mathrm{~nm}$. The MDA content was determined as follows:

$$
\begin{aligned}
A=[A b s & 532_{+T B A}-A b s 600_{+T B A} \\
& \left.-\left(\text { Abs } 532_{-T B A}-A b s 600_{-T B A}\right)\right]
\end{aligned}
$$

$$
\begin{gathered}
B=\left[\left(\text { Abs } 440_{+T B A}-\text { Abs } 600_{+T B A}\right)\right. \\
* 0.0571]
\end{gathered}
$$

Experimental design and statistical analysis

A design in factorial arrangement was conducted with eight plants per treatment, where the primary factor was the rice genotypes ('F60', 'LV447', 'FLO2764', 'LV1401', 'CT19021', and 'IR1561') and the secondary factor was the night temperature $\left(24\right.$ vs. $\left.30^{\circ} \mathrm{C}\right)$. When significant differences were present, a means comparison test of the treatments was performed using the Tukey test. Data were analyzed using SPSS software (v20.0, IBM Company, USA).

\section{Results and Discussion}

Photosynthesis, Carboxylation Efficiency and Intrinsic Water Use Efficiency (WUE $E_{i}$

A high night temperature $\left(30{ }^{\circ} \mathrm{C}\right)$ reduced leaf photosynthesis $\left(\mathrm{P}_{\mathrm{n}}\right)$ in all the genotypes (Fig. 1). Overall, $\mathrm{P}_{\mathrm{n}}$ was reduced by 35 to $40 \%$ in all rice genotypes at $30^{\circ} \mathrm{C}$. Similar trends were found in the carboxylation efficiency and intrinsic water use efficiency (WUEi) under a high nighttime temperature (HNT) (Fig. 1). WUEi showed a greater drop (approximately 75\%) in plants under HNT than the control ones. Finally, no differences were found in the internal $\mathrm{CO}_{2}$ concentration (Ci) (Fig. 1). The adverse effects of HNT on leaf photosynthesis also has been reported in rice (Mohammed $e t$ al., 2013) and sorghum (Prasad and Djanaguiraman, 2011). The decrease in $\mathrm{P}_{\mathrm{n}}$ under HNT can be associated with a reduction in stomatal conductance (Mohammed et al., 2013) and alterations in plant carbohydrate content because of the lower hexose and sucrose concentrations in heat-stressed leaves (Loka and Oosterhuis, 2016).

\section{Plant respiration}

Differences were also observed between night temperatures on total plant respiration in all rice genotypes (Fig. 2). In general, total plant respiration was higher when the night temperature increased, especially in the 'CT19021, 'FLO2764', 'IR1561', 'LV1401' and 'LV447' genotypes. In this regard, 'LV1401' plants showed the largest increase (approximately 75\%) in the total plant respiration rate. Furthermore, 'F60' plants did not show changes in two different night temperatures, suggesting an acclimatization response in this genotype. Mohammed and Tarpley (2009) and Peraudeu et al. (2015a) also reported a 30\% increase in night respiration during nighttime temperatures $\left(\geq 27^{\circ} \mathrm{C}\right)$. Plant respiration is the primary source of energy, fueling growth and maintenance processes in plants, but it can also be seen as a metabolic cost that limits carbon availability for crop productivity (Peraudeu et al., 2015b). In this regard, a higher plant respiration rate in response to HNT is associated with greater carbohydrate consumption, suggesting a role in the demand for ATP or other respiratory products (Turnbull et al. 2002; Peraudeu et al., 2015b). In support of that observation, Loka and Oosterhuis (2016) reported that HNT increased leaf respiration, but they simultaneously observed that ATP levels were markedly decreased. On the other hand, Atkin and Tjoelker (2003) stated that there are two acclimation types of 

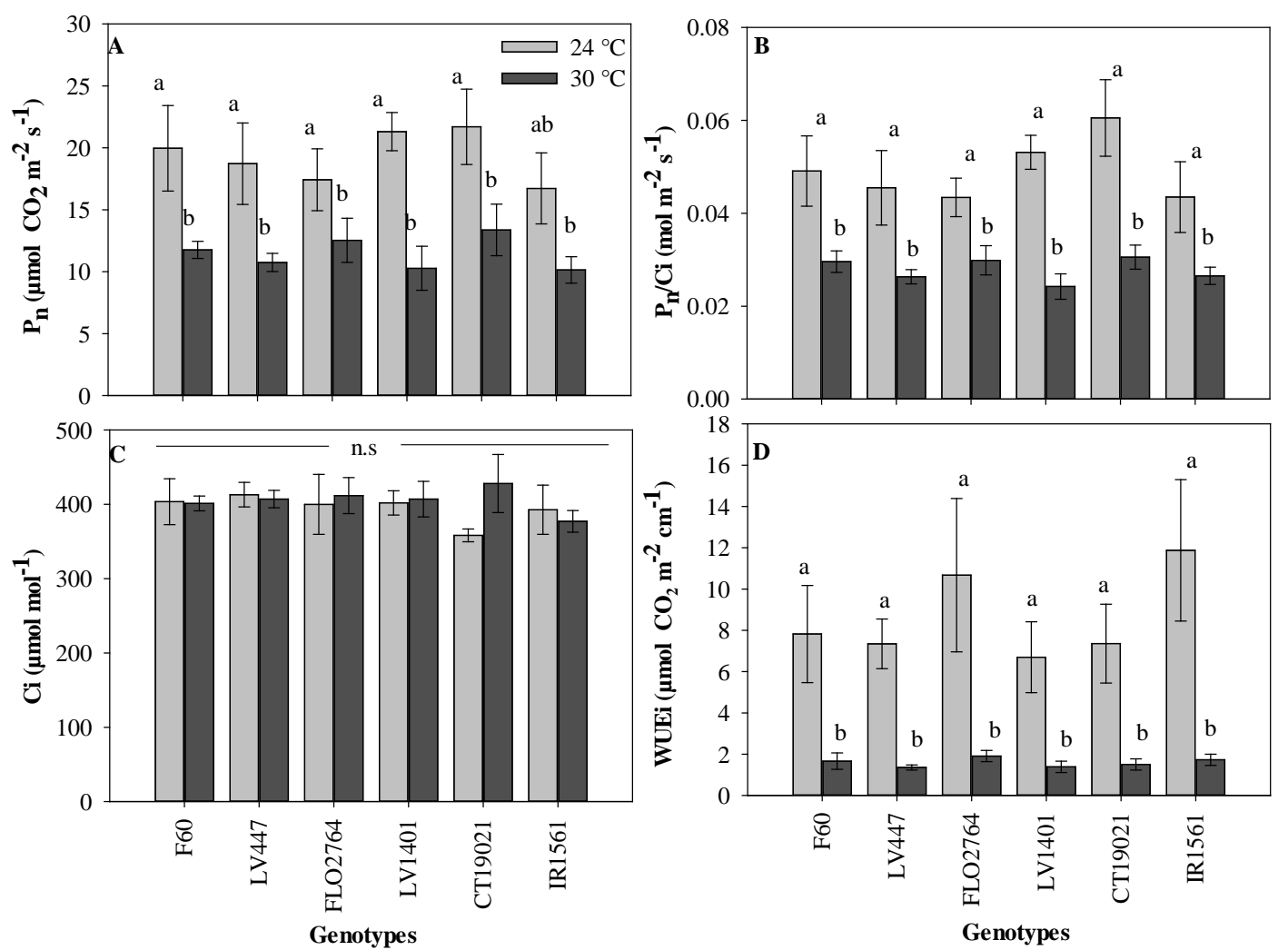

Fig. 1. Effect of two nighttime temperatures $\left(24\right.$ vs. $\left.30^{\circ} \mathrm{C}\right)$ on leaf photosynthesis $(\mathrm{A})$, carboxylation efficiency $\left(\mathrm{P}_{\mathrm{n}} / \mathrm{C}_{\mathrm{i}}\right)(\mathrm{B})$, intercellular $\mathrm{CO}_{2}\left(\mathrm{C}_{\mathrm{i}}\right)(\mathrm{C})$, and intrinsic water use efficiency $\left(\mathrm{WUE}_{\mathrm{i}}\right)(\mathrm{D})$ in rice genotypes. Each bar chart represents the mean of 6 plants. Vertical bars represent \pm standard error. Means followed by the same letter are not significantly different at $p \leq 0.05$ according to Tukey's test

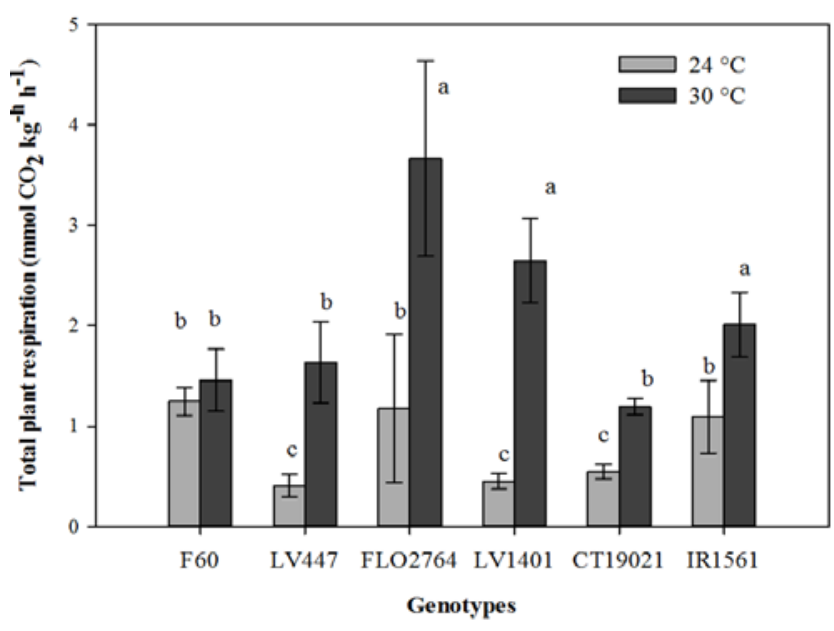

Fig. 2. Effect of two nighttime temperatures $\left(24\right.$ vs. $\left.30^{\circ} \mathrm{C}\right)$ on total plant respiration in rice genotypes. Each bar chart represents the mean of 6 plants. Vertical bars represent \pm standard error. Means followed by the same letter are not significantly different at $p \leq 0.05$ according to Tukey's test

plant respiration to temperature. In Type I, plant respiration is constant at low temperatures, regardless of the growth temperature, and responds to higher temperatures with a lower Q10 if the plants are acclimated to them. In Type II (homeostasis), plant respiration is lower in warm-acclimated plants, regardless of the temperature studied, and Q10 does not necessarily change with the growth temperature. This could explain the lack of variation in the plant respiration of the 'F60' plants. This genotype might have a Type II strategy under HNT, which suggests that it would have better availability of the redox state of its ubiquinone pool than the other genotypes (Atkin and Tjoelker, 2003).

\section{Growth variables}

Distinct differences were found in the leaves, stem, and total dry mass, leaf area and leaf/stem ratio $(P \leq 0.05)$ due to genotypes and temperatures (Table 1). HNT reduced approximately $55 \%$ of the biomass in leaves $(152.72 \mathrm{~g})$, stem $(111.43 \mathrm{~g})$ and total $(11.43 \mathrm{~g})$ dry weights compared to plants grown under the control conditions (307.04 g in leaves, 313.31 $\mathrm{g}$ in stems and $602.36 \mathrm{~g}$ in total biomass). Additionally, a lower leaf area was recorded at $30^{\circ} \mathrm{C}$ where control plants $\left(24^{\circ} \mathrm{C}\right)$ showed a higher leaf size than HNT plants $(66.64 \mathrm{~cm}$ vs. 33.64 $\mathrm{cm}$, respectively). Regarding genotypes, 'F60'seedlings had the greatest biomass accumulation and leaf area compared to other genotypes. However, the 'LV1401' genotype seedlings had the highest specific leaf area. In general, a lower plant biomass in rice plants subjected to $30^{\circ} \mathrm{C}$ could be due to a balance between photosynthesis and night respiration in rice plants (Cheng et al., 2009; Mohammed et al., 2013). HNT causes a lower photosynthetic rate and increased respiration, and it can adversely affect membrane stability, causing a lower biomass accumulation (Peng et al., 2004). Similar observations were obtained by Zhang et al. (2013), where HNT $\left(27.4^{\circ} \mathrm{C}\right)$ caused a lower biomass accumulation due to impaired crop growth rate. On the other hand, the differences in growth parameters among genotypes may be primarily attributed to varietal 
Table 1. Effect of two nighttime temperatures $\left(24 \mathrm{vs.} 30^{\circ} \mathrm{C}\right)$ on growth parameters in rice genotypes

\begin{tabular}{|c|c|c|c|c|c|c|}
\hline $\begin{array}{l}\text { Treatment/ } \\
\text { Parameter }\end{array}$ & $\begin{array}{c}\text { Total Dry Mass } \\
(\mathrm{mg})\end{array}$ & $\begin{array}{c}\text { Leaves Dry Mass } \\
(\mathrm{mg})\end{array}$ & $\begin{array}{l}\text { Stem Dry } \\
\text { Mass (mg) }\end{array}$ & $\begin{array}{c}\text { Leaf/Stem Ratio (mg } \\
\left.\mathrm{mg}^{-1}\right)\end{array}$ & $\begin{array}{l}\text { Leaf Area } \\
\left(\mathrm{cm}^{-2}\right)\end{array}$ & $\begin{array}{l}\text { Specific Leaf Mass } \\
\qquad\left(\mathrm{mg} \mathrm{cm}^{-1}\right)\end{array}$ \\
\hline \multicolumn{7}{|c|}{ Genotype } \\
\hline F60 & $521.23 \mathrm{a}^{\mathrm{z}}$ & $281.55 \mathrm{a}$ & 239.67 & $1.28 \mathrm{a}$ & $61.08 \mathrm{a}$ & $4.67 \mathrm{bc}$ \\
\hline LV447 & $477.98 \mathrm{ab}$ & $254.62 \mathrm{ab}$ & 223.27 & $1.22 \mathrm{a}$ & $57.51 \mathrm{ab}$ & $4.45 c$ \\
\hline FLO2764 & $378.25 \mathrm{~b}$ & $201.39 b c$ & 176.85 & $1.22 \mathrm{a}$ & $45.16 \mathrm{bc}$ & $4.55 \mathrm{bc}$ \\
\hline LV1401 & $361.62 \mathrm{~b}$ & $173.65 c$ & 187.96 & $1.04 \mathrm{~b}$ & $33.00 \mathrm{c}$ & $5.22 \mathrm{a}$ \\
\hline СТ19021 & $395.17 \mathrm{ab}$ & $210.79 b c$ & 184.38 & $1.24 \mathrm{a}$ & $50.02 \mathrm{ab}$ & $4.21 \mathrm{c}$ \\
\hline IR1561 & $477.29 \mathrm{ab}$ & $242.94 \mathrm{ab}$ & 234.85 & $1.17 \mathrm{ab}$ & $48.63 \mathrm{abc}$ & $5.03 \mathrm{ab}$ \\
\hline Significance & $* * * y$ & $* * *$ & NS & $* * *$ & $* * *$ & $* * *$ \\
\hline \multicolumn{7}{|c|}{ Temperature $\left({ }^{\circ} \mathrm{C}\right)$} \\
\hline 24 & 620.36 & 307.04 & 313.31 & 0.99 & 66.64 & 4.74 \\
\hline 30 & 254.15 & 152.72 & 111.43 & 1.36 & 33.64 & 5.66 \\
\hline Significance & *** & *** & *** & *** & *** & NS \\
\hline \multicolumn{7}{|c|}{ Temperature ${ }^{*}$ Genotype } \\
\hline Significance & NS & NS & NS & NS & NS & NS \\
\hline
\end{tabular}

${ }^{\overline{ }}$ Means with different letters represent statistically significant differences according to Tukey's test $(\mathrm{p} \leq 0.05)$

${ }^{y}$ N.S. and ${ }^{* * *}$ represent Non Significance and Significance at $\mathrm{P} \leq 0.001$, respectively.

Table 2. Effect of two nighttime temperatures $\left(24 \mathrm{vs} .30^{\circ} \mathrm{C}\right)$ on leaf photosynthetic pigments and proline content in rice genotypes

\begin{tabular}{|c|c|c|c|c|c|c|c|}
\hline Parameter & $\begin{array}{c}\text { CAR } \\
\left(\mathrm{mg} \mathrm{g}^{-1}\right)\end{array}$ & $\begin{array}{c}\mathrm{Chl} \mathrm{a} \\
\left(\mathrm{mg} \mathrm{g}^{-1}\right)\end{array}$ & $\begin{array}{l}\text { Chl b } \\
\left(\mathrm{mgg} \mathrm{g}^{-1}\right)\end{array}$ & $\begin{array}{l}\text { Chl Total } \\
\left(\mathrm{mg} \mathrm{g}^{-1}\right)\end{array}$ & $\mathrm{Chl} \mathrm{a/b}$ & Chl/CAR & $\begin{array}{c}\text { Proline } \\
\left(\mu \mathrm{mol} \mathrm{g}^{-1}\right)\end{array}$ \\
\hline \multicolumn{8}{|c|}{ Genotype } \\
\hline F60 & 0.84 & 2.60 & $0.91 \mathrm{ab}^{\mathrm{z}}$ & $3.46 \mathrm{~b}$ & $2.88 \mathrm{~b}$ & 4.34 & 0.22 \\
\hline LV447 & 0.98 & 3.31 & $1.08 \mathrm{ab}$ & $4.40 \mathrm{ab}$ & $3.05 \mathrm{ab}$ & 4.73 & 0.25 \\
\hline FLO2764 & 1.09 & 3.80 & $1.14 \mathrm{ab}$ & $4.78 \mathrm{ab}$ & $3.43 \mathrm{a}$ & 4.39 & 0.25 \\
\hline LV1401 & 0.78 & 2.77 & $0.90 \mathrm{~b}$ & $3.67 \mathrm{ab}$ & $3.11 \mathrm{ab}$ & 4.75 & 0.22 \\
\hline СТ19021 & 1.10 & 3.98 & $1.41 \mathrm{a}$ & $5.39 a$ & $2.90 \mathrm{~b}$ & 4.97 & 0.23 \\
\hline IR1561 & 0.98 & 3.07 & $1.01 \mathrm{ab}$ & $4.08 \mathrm{ab}$ & $3.04 a b$ & 4.22 & 0.29 \\
\hline Significance & NS & NS & $*$ & ${ }^{*}$ & ${ }^{*}$ & NS & NS \\
\hline \multicolumn{8}{|c|}{ Temperature $\left({ }^{\circ} \mathrm{C}\right)$} \\
\hline 24 & 0.85 & 3.0 & 1.0 & 3.99 & 3.03 & 4.77 & 0.22 \\
\hline 30 & 1.10 & 3.5 & 1.15 & 4.66 & 3.03 & 4.30 & 0.26 \\
\hline Significance & **y & NS & NS & * & NS & ** & NS \\
\hline \multicolumn{8}{|c|}{ Genotype*Temperature } \\
\hline Significance & NS & NS & NS & NS & NS & NS & NS \\
\hline
\end{tabular}

${ }^{\mathrm{z}}$ Means with different letters represent statistically significant differences according to Tukey's test $(\mathrm{p} \leq 0.05)$

${ }^{y} \mathrm{NS}$, and ${ }^{* * *}$ represent Non significance and significance at $\mathrm{P} \leq 0.05$ or $\mathrm{P} \leq 0.01$, respectively.

differences, since ANOVA did not show differences in the interaction (Zhang et al., 2013; Garcés-Varon and RestrepoDíaz, 2015).

\section{Chlorophyll fluorescence and leaf photosynthetic pigments}

Additionally, distinct differences were found between factors (nighttime temperatures and genotypes) on the $F_{v} / F_{m}$ ratio and leaf photosynthetic pigments (chlorophyll and carotenoids). A lower $\mathrm{F}_{\mathrm{v}} / \mathrm{F}_{\mathrm{m}}$ ratio was found in rice plants at 30 ${ }^{\circ} \mathrm{C}$ than $24^{\circ} \mathrm{C}$ ( 0.79 vs. 0.74 , respectively) (Fig. 3 ). Regarding genotypes, 'FLO2764', 'LV1401' and 'IR1561' plants showed a higher ratio at the end of the experiment than the others (data not shown). A drop in PSII efficiency $\left(\mathrm{F}_{\mathrm{v}} / \mathrm{F}_{\mathrm{m}}\right.$ ratio) may be due to damage in the PSII proteins, usually D1 and/or impairments of the repair system of this protein (Gururani et al., 2015). On the other hand, HNT caused an increase in leaf carotenoid and chlorophyll content, but a lower chlorophyll/carotenoid ratio was observed. Moreover, differences were found in leaf chlorophyll $b$, total content and chlorophyll a/b ratio among genotypes, where 'FLO2764' plants showed the highest contents (Table 2). In general, HNT mainly caused a higher leaf carotenoid content and a lower chlorophyll/carotenoid ratio. A higher carotenoid content is a tolerance mechanism under heat stress conditions because carotenoids can dissipate energy in the form of heat through the xanthophyll cycle or can act as antioxidants (Jahns and Holzwarth, 2012). A lower ratio also indicates an acclimatization response to high temperatures (Wahid et al., 2007).

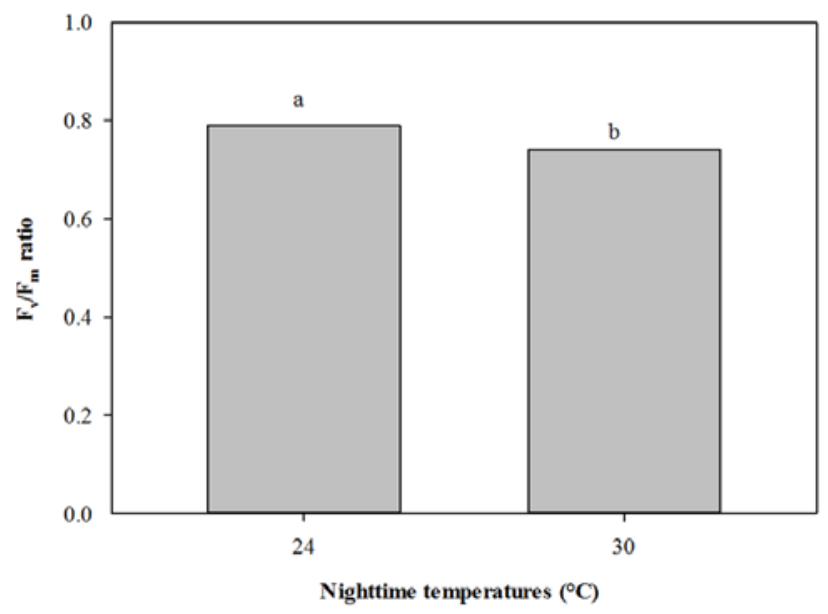

Fig. 3. Effect of two nighttime temperatures $\left(24\right.$ and $\left.30^{\circ} \mathrm{C}\right)$ on $\mathrm{F}_{\mathrm{v}} / \mathrm{F}_{\mathrm{m}}$ ratio readings in rice leaves. Vertical bars represent \pm standard error. Means followed by different letter are significantly different at $p \leq 0.05$ according to Tukey's test 
162

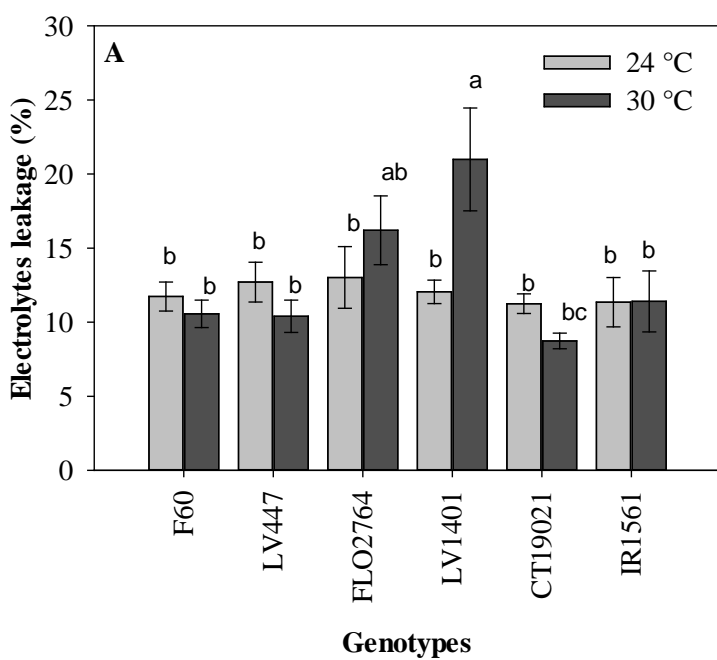

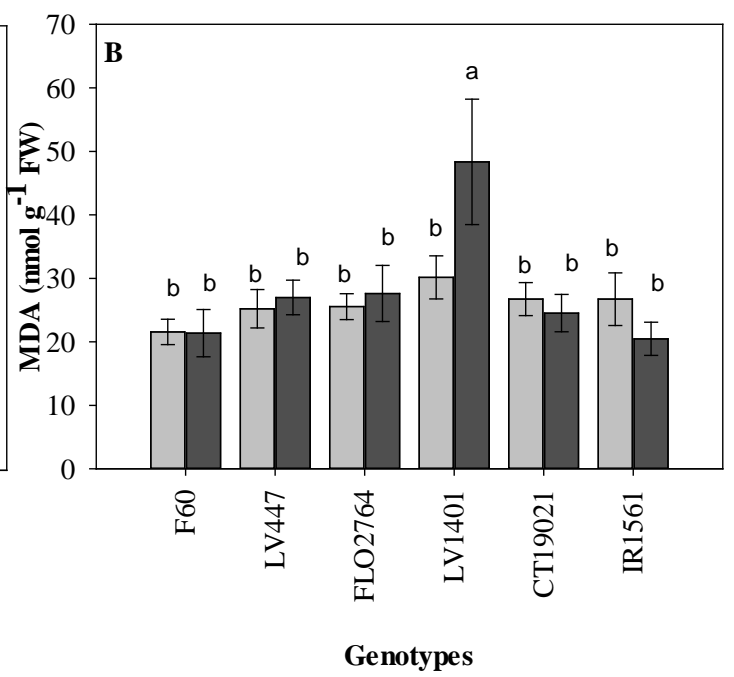

Fig. 4. Effect of two nighttime temperatures $\left(24\right.$ and $\left.30^{\circ} \mathrm{C}\right)$ on electrolyte leakage $(A)$ and MDA content $(B)$ in rice genotypes. Each bar chart represents the mean of 6 plants. Vertical bars represent \pm standard error. Means followed by the same letter are not significantly different at $p \leq 0.05$ according to Tukey's test

\section{Electrolyte leakage, $M D A$, proline and photosynthetic pigments}

Differences were only found $(P \leq 0.05)$ in the interaction between genotype vs. night temperatures on MDA and electrolyte leakage in rice leaves (Fig. 4). At $30^{\circ} \mathrm{C}$, 'LV1401' seedlings had the highest membrane lipid peroxidation. Similar trends were also found for electrolyte leakage. A higher MDA content is often used as an indicator of oxidative damage (Sanchez-Reinoso et al., 2014). In this aspect, an increased MDA content in rice leaves under HNT indicates that the production of ROS is greater than in the control plants (Shah et al., 2011). Similar observations, where HNT affects membrane stability in susceptible genotypes, were also reported in wheat, sorghum and soybean (Prasad et al., 2008, Prasad and Djanaguiraman 2011, Djanaguiraman et al., 2013). On the other hand, Mohammed and Tarpley (2009) reported that susceptible rice genotypes under HNT showed a low total antioxidant capacity, resulting in higher electrolyte leakage. The previous statement could help explain the fact that 'LV1401' seedlings showed higher membrane damage in our experiment. Finally, no differences in proline content among genotypes and/or temperatures were found (Table 2). The lack of differences on leaf proline levels under HNT can be associated with low oxidative damage in almost all genotypes, since this amino acid has been recognized as a multi-functional molecule under abiotic stresses, showing a role as an antioxidant (Kishor and Sreenivasulu, 2014).

\section{Conclusions}

In summary, physiological traits, such as photosynthesis and respiration, as well as biochemical markers (MDA content), helped to expand our knowledge of the tolerance mechanism to heat stress in rice genotypes grown in tropical regions. Based on our results, we can conclude that a high night temperature $\left(30{ }^{\circ} \mathrm{C}\right)$ may cause a decrease in the leaf photosynthesis rate and increased respiration of susceptible genotypes. Biochemical traits, such as MDA and leaf chlorophyll/carotenoid ratio, can also be considered for screening tolerant genotypes since these parameters suggest oxidative damage under HNT. Finally, our results also suggest that 'F60' plants might represent a genotype that shows acclimatization to high night temperature conditions, and they can be cultivated in regions where periods of extremely high night temperatures can be expected.

\section{References}

Alvarado-Sanabria O, Garces-Varon G, Restrepo-Diaz H (2017). Physiological response of rice seedlings (Oryza sativa $\mathrm{L}$ ) subjected to different periods of two night temperatures. Journal of Stress Physiology and Biochemistry 13:35-43.

Araus JL, Slafer GA, Royo C,Serret MD (2008). Breedingfor yield potential and stress adaptation in cereals. Critical Reviews in Plant Sciences 27:377 412 .

Atkin OK, Tjoelker MG (2003). Thermal acclimation and the dynamic response of plant respiration to temperature. Trends in Plant Science 8: 343-351.

Ballesteros HO, Enciso CE (2012). Indicators reflecting changes in the climate system Colombia (hottest years and decades and more and less rainy). Retrieved 2017 March 13 from http://www.ideam.gov.co/ web/tiempo-y-dima/escenarios-cambio-dimatico.

Bates LS, Waldren RP, Teare ID (1973). Rapid determination of free prolinefor water-stressstudies. Plant and Soil 39:205-207.

Bita C, Gerats T (2013). Plant tolerance to high temperature in a changing environment: scientific fundamentals and production of heat stress tolerant crops. Frontiers in Plant Science 4:1-18.

Cheng W, Sakai H, Yagi K, Hasegawa T (2009). Interactions of elevated $[\mathrm{CO} 2]$ and night temperature on rice growth and yield. Agricultural and Forest Meteorology 149:51-58.

Djanaguiraman M, Prasad PVV, Schapaugh WT (2013). High day- or nighttime temperature alters leaf assimilation, reproductive success, and phosphatidic acid of pollen grain in soybean [Glycine max (L.) Merr.]. CropScience 53: 15941604

FAO (2002). World agriculture: towards 2015/2030. Summary report. 
Retrieved 2017 March 13 from http://www.fao.org/docrep/004/ y3557s/y3557s00.htm.

FEDEARROZ (2013). Integrated rice crop management. Produmedios, Colombia.

Garcés-Varon G, Restrepo-Díaz, H (2015). Growth and yield of rice cultivars sowed on different dates under tropical conditions. Ciencia e Investigacion Agraria 42:217-226.

Gururani MA, Venkatesh J, Tran LSP (2015). Regulation of photosynthesis during abiotic stress-Induced Photoinhibition. Molecular Plant 8:1304 1320.

Hasanuzzaman M, Nahar K, Alam MM, Roychowdhury R, Fujita M (2013). Physiological, biochemical, and molecular mechanisms of heat stress tolerance in plants. International Journal of Molecular Sciences 14:9643-9684.

Hodges DM, DeLong JM, Forney CF, Prange RK (1999). Improving the thiobarbituric acid-reactive-substances assay for estimating lipid peroxidation in plant tissues containing anthocyanin and other interferingcompounds. Planta 207:604611.

Jahns P, Holzwarth AR (2012). The role of the xanthophyll cycle and of lutein in photoprotection of photosystem II. Biochimica et Biophysica Acta-Bioenergetics 1817:182-193.

Jha UC, Bohra A, Singh NP (2014). Heat stress in crop plants: its nature, impacts and integrated breeding strategies to improve heat tolerance. Plant Breeding 133:679-701.

Kanno K, Mae T, Makino A (2009). High night temperature stimulates photosynthesis, biomass production and growth during the vegetative stage of rice plants. Soil Science and Plant Nutrition 55:124131.

Kishor PVK, Sreenivasulu N (2014). Is proline accumulation per se correlated with stress tolerance or is proline homeostasis a more critical issue?. Plant Cell and Environment 37:300-311.

Kumar S, Gupta D, Nayyar H (2012). Comparative response of maize and rice genotypes to heat stress: status of oxidative stress and antioxidants. Acta Physiologiae Plantarum 34:75-86.

Kumar N, Shankhdhar SC, Shankhdhar D (2016). Impact of elevated temperature on antioxidant activity and membrane stability in different genotypes of rice (Oryza sativa L.). Indian Journal of Plant Physiology 21:37-43.

Laza MRC, Sakai H, Cheng W, Tokida T, Peng S, Hasegawa T (2015). Differential response of rice plants to high night temperatures imposed at varying developmental phases. Agricultural and Forest Meteorology 209-210:69-77.

Lichtenthaler HK (1987). Chlorophylls and carotenoids: pigments of photosynthetic biomembranes. Methods in Enzymology 148:350-382.

Loka DA, Oosterhuis DM (2016). Increased night temperatures during cotton's early reproductive stage affect leaf physiology and flower bud Carbohydrate content decreasing flower bud retention. Journal of Agronomy and CropScience 202:518-529.

Mohammed AR, Tarpley L (2009). Impact of high nighttime temperature on respiration, membrane stability, antioxidant capacity, and yield of rice plants. CropScience 49:313-322.
Mohammed AR, Tarpley L (2010). Effects of high night temperature and spikelet position on yield-related parameters of rice (Oryza sativa L.) plants. European Journal of Agronomy 33:117-123.

Mohammed R, Cothren JT, Tarpley L (2013). High night temperature and abscisic acid affect rice productivity through altered photosynthesis, respiration and spikelet fertility. CropScience 53:2603-2612.

Peng S, Huang J, Sheehy JE (2004). Rice yields decline with higher night temperature from global warming. Proceedings of the National Academy of Sciences of the United States of America 101:9971-9975.

Peraudeau S, Roques S, Quiñones CO, Fabre D, Rie JV, Ouwerkerk PBF, Jagadish KSV, Dingkuhn M, Lafarge T (2015a). Increase in night temperature in rice enhances respiration rate without significant impact on biomass accumulation. Field Crops Research 171:67-78.

Peraudeau S, Lafarge T, Roques S, Quiñones CO, Vidal AC, Ouwerkerk PBF, Rie JV, Fabre D, Jagadish KSV, Dingkuhn M (2015b). Effect of carbohydrates and night temperature on night respiration in rice. Journal of Experimental Botany 66:3931-3944.

Prasad PVV., Pisipati SR, Ristic Z, Bukovnik U, Fritz AK (2008). Impact of nighttime temperature on physiology and growth of spring wheat. Crop Science 48:2372-2380.

Prasad PVV, Djanaguiraman M (2011). High night temperature decreases leaf photosynthesis and pollen function in grain sorghum. Functional Plant Biology 38:993-1003.

Sánchez-Reinoso AD, Garcés-Varón G, Restrepo-Díaz H (2014). Biochemical and physiological characterization of three rice cultivars under different daytime temperature conditions. Chilean Journal of Agricultural Research 74:373-379.

Shah F, Huang J, Cui K, Nie L, Shah T, Wu W, WangK, Khan ZH, Zhu L, Chen C (2011). Physiological and biochemical changes in rice associated with high night temperature stress and their amelioration by exogenous application of ascorbic acid (vitamin C). Australian Journal of CropScience 13:1810-1816.

Turnbull MH, Murthy R, Griffin KL (2002). The relative impacts of daytime and night-time warming on photosynthetic capacity in Populus deltoides Plant Cell and Environment 25:1729-1737.

Wahid A, GelaniS, AshrafM, Foolad MR(2007). Heat tolerance in plants: An overview.Environmental and Experimental Botany 61:199-223.

Xue DW, Jiang H, Hu J,Zang XQ, Guo LB, Zeng DL, Dong GJ, Sun GC, Qian Q (2012). Characterization of physiological response and identification of associated genes under heat stress in rice seedlings. Plant Physiology and Biochemistry 61:46-53.

Yin Y, Li S, Liao W, Lu Q, Wen X, Lu C (2010). Photosystem II photochemistry, photoinhibition, and the xanthophyll cycle in heatstressed riceleaves. Journal of Plant Physiology 167:959-966.

Zhang Y, TangQ, PengS,Zou Y, Chen S, Shi W, Qin J,LazaMRC (2013). Effects of high night temperature on yield and agronomic traits of irrigated rice under field chamber system condition. Australian Journal CropScience 7:7-13. 